\title{
Managing resource dependencies in electric vehicle supply chains: a multi-tier case study
}

\begin{abstract}
Purpose - To investigate dependencies that arise between companies during the rampup of production volume in the electric vehicle (EV) supply chain.

Design/methodology/approach - An inter-company case study method has been used. Data was collected via tours of manufacturing plants, workshops and interviews from multiple tiers in a supply chain, namely a niche EV manufacturer, as well as two of its tier one suppliers and five of its tier two suppliers.

Findings - As production volumes increased, a more relational approach was found to be necessary in inter-company relationships. Our research showed that key suppliers, in addition to providing the parts, pursued a supply chain orchestrator's role by offering direct support and guidance to the niche EV manufacturer in designing and executing its development plans.
\end{abstract}

Research limitations/implications - Resource Dependence Theory (RDT) is used to analyse and explain the changing dependencies throughout the planning and execution of production ramp-up.

Practical implications - This study will help supply chain managers to better manage resource dependencies during production ramp-up.

Originality/value - This study explores dependencies during the early stages of the production ramp-up process in the EV sector, which is in itself in the early stages of evolution. RDT is employed for the first time in this context. This study has moved beyond a simple dyadic context, by providing empirical insights into the actions taken by an EV manufacturer and its suppliers, toward a multi-tier supply chain context, to better manage resource dependencies.

Keywords - Electric Vehicle, Resource Dependence Theory, Supply Chain Management, Production Ramp-up, Case Study.

Paper type - Research paper 


\section{Introduction}

The electrification of transportation is widely considered to be a viable strategic alternative to oil dependency and its associated harmful environmental impacts; governments in different countries have recognised this as an opportunity. For example, the US Electric Vehicle (EV) industry has had strong growth, exemplified by the California-based start-up, Tesla Motors, which has now gained a significant market share, with nearly 57,000 electric cars sold. The UK, over the last three years, has also seen a remarkable surge in demand for EVs. New registrations of plug-in cars has increased from 3,500 in 2013 to more than 166,000 by August 2018 (Lilly, 2018). It is projected that the overall number of electric vehicles could range from 9 million to 20 million by 2020 and from 40 million to 70 million by 2025 (IEA, 2017). EV manufacturers must therefore ramp up their production output to meet an increasing demand for EVs (Andersen et al., 2016). Yet manufacturers face a number of supply chain challenges. For example, the supply of batteries for EVs has been identified as a potential constraint for Tesla Motors, due to the scarcity of lithium hydroxide and rare earth metals needed for the batteries (Kam, 2016).

Production ramp-up issues have received attention in the automotive industry (e.g. Almgren, 2000; Held, 2010; Surbier et al., 2014), but supply chain implications specific to the emerging EV sector have received less emphasis. Therefore, there are a number of factors in the EV sector that require further exploration and explanation, especially as some of the technologies are still immature (e.g. battery systems, fuel cells, supporting infrastructure). For instance, the EV industry's new innovative products are undergoing continuous modification, while the industry's new business models are rapidly changing and often significantly vary from the business models associated with traditional internal combustion engine (ICE) vehicles (Rossini et al., 2016; Klug, 2013). 
Moreover, EV supply chains have not yet been fully established, as companies are often start-ups or small-to-medium sized enterprises (SMEs) with limited resources (Clegg, 2018). These start-ups and SMEs may not be currently involved in traditional ICE automotive supply chains. However, these companies may go on to become critical players in future EV supply chains (Bierau et al., 2015; Rossini et al., 2016). Research efforts (e.g. Terwiesch and Bohn, 2001; Niroomand et al., 2012) have so far explored the implications of 'internal production' ramp-up on various metrics of manufacturing performance, such as quantity of product, cost, quality. But fewer researchers have highlighted the role of resource dependence connections in multi-tier case studies (e.g. Christensen and Karlsson, 2016; Filla and Klingebiel, 2014). Issues relating to resource dependency in EV supply chains will become more pressing in the future, as governments and original equipment manufacturers (OEMs) mandate, and in some cases outlaw, wholly ICE powered vehicles.

In response to the research context described above, this paper provides insights into a multi-tiered supply chain case study that focuses on a niche EV manufacturer, referred to as EV-Co (the company's name has been changed to preserve its anonymity). This case study also encompasses the EV manufacturer's suppliers of those drivetrainrelated components that most distinguish the EV from an ICE vehicle (e.g. motor, battery, fuel cells, and electronic control units). The identity of these suppliers is also disguised to preserve their anonymity.

EV-Co plans to move from producing five units to 30,000 units within five years. As a relatively new start-up company, EV-Co will be highly dependent upon its suppliers to achieve quick volume ramp-up and all-round improved operational and supply chain performance, in order to be able to overcome their resource deficiencies and the risks associated with expansion. To compound their relatively weak position in the supply 
chain, EV-Co presently accounts for a very low average proportion (about 10\%) of their suppliers' sales/revenue; this gives EV-Co very little relative buying power. This study, in part, adds much-needed insight into how buyer dependence on suppliers (Kähkönen et al., 2015) during production ramp-up can be better managed. This study explores and attempts to explain strategies to positively develop supply chain relationships/dependencies during production ramp-up activities, based on specific contingency factors. Thus, there are two specific questions that drive this research:

Research Question 1. What factors influence the level of dependence of niche manufacturing companies on their suppliers' resources during production ramp-up in an EV supply chain?

Research Question 2. What strategies can be used by niche manufacturing companies to manage their resource dependencies during the production rampup in an EV supply chain?

In this study, Resource Dependence Theory (RDT) was chosen as a theoretical basis to explain research findings, because of its primary emphasis on strategic resources that are owned and controlled by companies using power, position and role differences. Other theories (e.g. Resource Based View, Transaction Cost Economics, and Relational View) would be less relevant, because of their lack of focus on asymmetric power-based strategies for resource distribution and the need to gain control over external resources.

RDT was used to analyse dependencies in this multi-tier supply chain study, and study resource dependencies, because the focal company (EV-Co) was very highly dependent on its suppliers to cope with such ambitious production ramp-up targets.

The remainder of this paper proceeds as follows. The paper starts with a literature review of studies in the EV sector, in respect of production ramp-up and supply chain management. Next, RDT is presented and its key elements discussed, followed by the 
research methodology and the case study findings. Lastly, conclusions and further research opportunities are set out.

\section{Literature review and theoretical background}

\subsection{Supply chain ramp-up in the emerging EV sector}

In recent years, EV technology has rapidly evolved and begun to disrupt the automotive industry (Weforum, 2017), as pathways towards environmentally sustainable post-ICE transportation solutions (Steinhilber et al., 2013) have become seen as viable.

In the supply chain management literature, previous studies have focused on sustainability issues (e.g. Hawkins et al., 2012; Günther et al., 2015; Juan et al., 2016). For instance, Hendrickson et al. (2015) investigated optimal locations for battery recycling in California. By contrast, other studies have examined impacts on traditional automotive supply chains, as EVs become more prolific (e.g. Klug, 2013; Rossini et al., 2016). Challenges associated with EV adoption and use, ranging from technical issues (e.g. battery technologies) to user-related concerns (e.g. range anxiety), have also been explored (Li et al., 2015, p. 371).

In the production ramp-up literature, previous studies have explored cost, quality and timeliness factors (e.g. Surbier et al., 2014), as well as the impact of late engineering design changes, effects of supply-chain network configuration, process and product complexity, and the degree of novelty (e.g. Elstner and Krause, 2014). Glock and Grosse (2015) reviewed quantitative decision support models for ramp-up planning by focusing on typical planning problems, and the process characteristics of the ramp-up phase. Other studies have proposed different ramp-up strategies. For example, Clark and Fujimoto (1991) proposed two different strategies for ramp-up of new products in final assembly, 
based on the choice of ramp-up curve, the operation pattern, and the workforce policy. Schuh et al. (2005) also proposed three production ramp-up strategies, namely 'slow motion', 'dedication' and 'step-by-step'; they advocated that the correct selection is dependent on specific parameters (such as utilisation, product variety, ramp-up time and decoupling level).

Despite this growing body of empirical research investigations into understanding resource dependence connections, and cases of how companies choose to develop their strategies to handle the associated issues of production ramp-up, knowledge is still currently limited (Christensen and Rymaszewska, 2016).

\subsection{Resource dependence theory and buyer-supplier relationships}

RDT states that organisations are open systems, dependent on their environment 'to obtain critical resources such as personnel, information, raw materials and technology' (Hirschheim et al., 2009, p. 176). According to RDT, companies that have access to scarce resources are able to influence other companies through their relationship with them (Casciaro and Piskorski, 2005).

Pfeffer and Salancik (2003) state that resource dependency levels are determined by three key factors: (i) the importance of the resource, (ii) the ease of supplier substitutability (i.e. availability of alternative suppliers and the associated switching costs), and (iii) the amount of 'discretion' (i.e. the ownership or ability to access and use) exerted (legislatively, geographically or politically) over the resource. Therefore, in respect to RDT, managers must strategise to minimise and overcome risky resource dependencies through either 'buffering' and/or 'bridging' strategies (Pfeffer and Salancik, 2003). 
Mindful of this, on the one hand, 'buffering' strategies are used to minimise resource dependencies on other firms by building up 'stocks' and reducing the uncertainty in obtaining important resources (Leonardi, 2013). On the other hand, 'bridging' strategies can be used to strengthen 'flows' between the source and sink of assets, and thus reduce the chance of crucial natural resource shortages by strengthening links through stronger strategic, operational and technical bridges between one firm and another (Leonardi, 2013). Such bridges can be thought of as 'boundary spanning' objects or activities, namely physical resources, people, skills and knowledge, and/or processes (Levina and Vaast, 2005) used across a multi-tier supply chain.

Several studies have applied RDT (Paulraj and Chen, 2007) to study the relationship between environmental uncertainties (demand, supply and technology) and strategic supply management, as supplier managers try to produce mutual benefits. Such collaborations should lead to accessing unique resources and minimise environmental uncertainties, as integration between companies increases. RDT has also been applied to discover factors that change buyer-supplier power dynamics, and to suggest appropriate mitigation strategies, as both directly affect and shape relational capital (Petersen et al., 2008).

Previous RDT studies (e.g. Kähkönen et al., 2015; Kalaitzi et al., 2018) in the field of supply chain management have investigated collaboration and bargaining power in times of uncertainty, but without considering the inherent uncertainty arising from production ramp-up in EV supply chains. These previous studies have also only focused on first-tier suppliers and the focal dyad has been between OEM and the first-tier supplier. Therefore, there is a need for research in this field to go beyond simple dyadic buyersupplier relationships (Hofmann et al., 2015), and to focus on multiple tiers of a supply 
chain, in order to generate more valuable insights (as per Mena et al., 2013; Tachizawa and Wong, 2014; Wilhelm et al., 2015).

\section{Methodology}

\subsection{Research context and approach}

Given the relative infancy of research into EV supply chain dependencies, as well as the infancy of research into buyer-supplier relationships during EV production ramp-up, an exploratory and explanatory inter-company case study was used to increase lucidity, as used in other similar studies (e.g. Barratt et al., 2011; Choudhari et al., 2012; Ketokivi and Choi, 2014; and Touboulic et al., 2014). A case study approach was used instead of a survey or quantitative approach, so that rich tacit data could be gathered to better understand the complex relationships underlying the ramp-up of production in the EV sector (as suggested by Voss, 2009; Edmonson and Mc Manus, 2007).

EV-Co was selected as the focal company in this multi-tier case study. EV-Co, founded in 2004, and based in the West Midlands in the UK, is an SME with seven fulltime employees. It specialises in the design of lightweight, hydrogen fuel and battery powered vehicles, with specific capabilities in areas such as mechanical engineering, fuel cell technology, hydrogen systems, battery systems, and whole vehicle development. EVCo produces a small hybrid fuel vehicle (i.e. a lightweight two-door, four-seater hybrid lithium ion battery vehicle intended for city use) referred to here as the 'City-Car', which forms the focus of this study.

The City-Car is currently in Stage 2 of the three overarching product development stages; namely 1) Research, Development and Planning 2) Prototype Building 3) Low/High Volume Production (Cuffaro et al., 2013). In this Prototype Building stage, 
supply chain management decisions become crucially important in respect of a successful product launch and production ramp-up later in the new product development life cycle, as path dependencies begin to form based on decisions about product and supply chain configurations (van Hoek and Chapman, 2007).

Our study takes a multi-tier approach, and focuses on the UK-centric drivetrain components of EV-Co's City-Car. The drivetrain of the City-Car forms 55\% of its overall cost (where the body forms $12 \%$, chassis $16 \%$, and electrical/electronic parts form $17 \%$ ). The unit of analysis for this study is EV-Co and its suppliers of the drivetrain-related systems and components within its City-Car supply chain. This study focuses on the relationships between EV-Co and two of its critical tier one suppliers and five of its tier two suppliers involved in the design, build and servicing of the City-Car in the UK (as highlighted in bold in Figure 1 below). This research focus is intended to create the potential to explore, capture and explain dependencies in the EV supply chain. It is worth highlighting that the battery or fuel cell suppliers were not based in the UK (and so not included directly in the case study).

-Insert Figure 1 Approximately Here

\subsection{Data collection and analysis}

Three appropriate and complementary sources of data were used (as per Edmondson and McManus, 2007): tours of the manufacturing plants; semi structured interviews; and workshops. Multiple sources of data were used to enhance both the reliability and construct validity of this study (as per Voss et al., 2002). The research was conducted from November 2016 to August 2017 in the UK (see Table 1). 
Plant tours were used as an initial source of data collection, thus facilitating direct observation. In total, ten plant tours of eight separate plants were arranged and facilitated by senior management from participating companies. Exploratory visits to plants were made in teams to reduce single-rater bias during data interpretations (Eisenhardt, 1989). Observational evidence allowed for a rich understanding of complex activities and plant resources (Ketokivi and Choi, 2014). The main purpose of the observation was to determine whether a plant could potentially fill a particular role during ramp-up. For example, Chassis-Co had an under-utilised area in the factory that could be used to support the ramp-up of City-Car whereas another company, Motor-Co, had to invest in new plant and facilities to increase their capacity to fulfil large new orders in line with EV-Co's new strategy. The plant tours also created an opportunity to ask insightful informal questions about inter-company relationships, thus helping to build a systemic model. Quantitative descriptive data (e.g. lead-times, number of suppliers, or the number of goods demanded per annum) were also collected during tours to characterise participating companies and demonstrate the magnitude of change and the magnitude of risk in the ramp-up plan.

After plant tours, semi-structured interviews were used as follow-up data collection to capture the core capabilities, capacities and performance deficiencies in the supply chain. Interviewees were selected based on purposive sampling, which found and chose participants based on their specific role and knowledge of the research topic (Creswell and Plano Clark, 2007). The interview process was continued until no new information was forthcoming, and researchers reached a point of theoretical saturation (Eisenhardt, 
1989). Theoretical saturation was reached when fourteen interviews had been conducted in total, and one additional interview was conducted to confirm theoretical saturation and verify that no more interviews were necessary. Thus, a total of fifteen interviews were conducted with directors and managers responsible for the production and logistics functions in the eight manufacturing companies. Depending on the participant's responses, interviews lasted between one and two hours. The interviews were conducted by a two-person team, an interviewer and a transcriber, to ensure that answers were fully captured.

Semi-structured interviews were based on three tools. Firstly, the 'Capability Matrix' was used for mapping companies' capabilities and supply chain capabilities. Secondly, the Process Orientated Holonic (PrOH) Modelling Methodology (Clegg, 2006; Clegg and Shaw, 2008) was used to visualise a high-level systemic overview of the changing dynamics of the automotive industry in a post-ICE dominated era, as PrOH modelling can provide the potential to understand how changes in one systemic success factor (whether it be social, economic, political or technological) can impact on other systemic success factors in an industry, business or supply chain. Thirdly, the Global Supply Chain Forum (GSCF) tool (Lambert, 2004) was used for analysing four specific processes, namely demand management; manufacturing flow management; supplier relationship management; product development; and commercialisation. The semistructured interview guide was based on these tools, and included detailed questions on the company's background, main players and distribution of power among them, as well as location of customers and suppliers, production volumes from suppliers, strategic sourcing policy, existing production processes and capabilities, lead-times and relative price of each component. An outline of the semi-structured interview was sent to the managers ahead of the meeting. These structured data collection techniques were used for 
qualitative data collection, so that reliability and theoretical maturity of the qualitative aspects of the research study were enhanced (Yin, 2003).

Two workshops were also held once an initial analysis of raw data from plant tours and interviews was completed. A two-stage approach to the analysis of the data was conducted (Miles and Huberman, 1994). In the first stage (Workshop 1), an intracompany analysis was conducted, focusing on different dependencies in each company, and coping strategies that each company followed to handle the dependencies. In the second stage (Workshop 2), a cross-company analysis was conducted to identify capabilities, processes and ramp-up issues across the supply chain, and capture common emergent themes using RDT. Objectivity, validity and reliability of the analysis were ensured by using pre-defined themes from the RDT framework (Miles and Huberman, 1994; King, 2004).

The first workshop (January 2017) brought together eight supply chain professionals: three academics, two practitioners (i.e. the directors of EV-Co and MotorCo), and two EV experts from an independent institute to discuss, refine, and extend the findings from plant tours and semi-structured questionnaires. From this first workshop, an initial systemic PrOH model was produced. The second workshop, held a month later, involved three academics, four practitioners (i.e. the directors of EV-Co, Motor-Co, Components-Co and Rotor-Co) and two experts from an independent institute to validate and update the initial $\mathrm{PrOH}$ model, and further focus on the 'big-picture' cross-company industry analysis. The next section explores the empirical findings produced by this methodology.

\section{Empirical findings: exploration}


EV-Co's supply chain was analysed in respect of resource dependencies with seven of its critical suppliers for the drivetrain and its interacting sub-systems and components. Exploratory findings from the PrOH model are initially given - to set EV-Co's supply chain into a wider social, economic and political context. An explanatory narrative, based on RDT, is then given of specific coping strategies - namely 'buffering' and 'bridging' strategies to manage resource dependencies in this context. RDT uses bridging and buffering as its key coping strategies (Bode et al., 2011; Meznar and Nigh, 1995). This study acknowledges that other theories can be used, but this study is focused on and restricted to RDT as an explanatory lens for its empirical findings. A template for constructing and reading a $\mathrm{PrOH}$ model is given in Appendix A.

\subsection{The PrOH Model - the wider context for EV-Co's supply chain}

-Insert Figure 2 Approximately Here-

The tacit systemic factors concerning EV supply chains obtained from the data collection activities are shown in the $\mathrm{PrOH}$ model, and further narrated below (all text is taken directly from Figure 2). By reading the core process statement from top left to bottom right in the $\mathrm{PrOH}$ model (Figure 2), the following dynamics are revealed.

The ICE-dominated era was influenced by socio-economic-political groups, such as consumer groups, incumbent industry groups and groups advocating on government legislation. These socio-economic-political groups are revising and reconsidering requirements for future transportation systems. These requirements include $\mathrm{CO}_{2}$ emissions reductions, material reuse and recycling, lower weight, closed loop supply chain logistics and infrastructure. In turn, these requirements are used for the design, build 
and maintenance of products by organisations of the automotive industry. For example, the organisations who deliver the gearbox, interiors, body, motors, materials, electronics, manual labour, batteries, engineering skills and knowledge, small components, pneumatics, drivetrains and fuel cell providers. These organisations deliver post-ICE dominated era transport systems; for example, closed loop supply chain and logistics systems, vehicles, business / service models, EV charging stations, hydrogen stations and telematics for IoT linked systems. These are all required by end-users of post-ICE transportation systems. These users will be the commuters, drivers and passengers in the post-ICE dominated era.

Systemic factors (in Figure 2) bring dramatic dynamic disruption to the automotive industry. For instance, organisations of the automotive industry will need to work in accordance with new operating characteristics; for example, more information sharing, more off-boarding, more collaborations through the supply chain, increased reliability, clearer supply chain strategy, more complete life cycle costing, more flexibility and modularity, unknowns / uncertainties, changing product complexities, more scalability of non-ICE vehicles, greater scientific bases and more globalisation. These operating characteristics are derived from the requirements for future transportation systems. The same future requirements for transportation systems are also used for the design, build and maintenance of these systems by organisations that are not traditionally part of the automotive industry; for example, off-board providers, computer manufacturers, highways agencies / toll road operators, energy companies, advanced services, civic authorities and providers of disruptive R\&D, all of whom could radically change post-ICE dominated era transport systems. In addition, further dynamism is brought about by post-ICE dominated era transport systems driven by new performance metrics; such metrics include increasing supplier metrics, reducing costs, leaner 
inventory, increasing IoT connectivity levels, whole life cycle emissions, changing utilities and reducing lead-times. These metrics affect incumbent organisations of the automotive industry, organisations not traditionally part of the automotive industry, and end users of post-ICE transportation systems (e.g. finance / leasing companies, driverless systems, commercial operating companies, private owners and car pools / clubs). Further dynamics of the post-ICE-dominated era transport systems are governed by newly emerging regulations; for example, taxations, recycling and use, European Union changes, data security, car sharing practice, civic / raid laws, insurance, and emissions / environmental legislation.

All in all, these dynamic systemic factors are complex and uncertain, which makes production ramp-up of EVs a challenging undertaking, particularly for smaller companies with less resources. The interconnections between these factors are shown in the PrOH model in Figure 2. Effectively managing resource dependencies between companies in this scenario is dynamic, complex and uncertain. The next section describes coping strategies, in respect to RDT, used by companies in this multi-tier case study.

\subsection{Resource dependence levels}

In this section, a detailed discussion of the EV-Co's ramp-up plans is given within the wider context described in Section 4.1 (c.f. Figure 2). Currently, EV-Co's level of production is low. They have an assembly capability of approximately five to twenty cars per year. Thus, to achieve economies of scale for both the EV-Co and its suppliers, significant steps need to be taken.

\subsubsection{Importance of the resource}


Concerning the importance of the resource, prices for certain drivetrain components are relatively high; components such as the hydrogen fuel system, magnets and fuel cell stacks. The prices can also fluctuate considerably. Components-Co (Director 1) stressed that, 'for yellow metals (i.e. a type of metal alloy that consists of $60 \%$ copper and $40 \%$ zinc) we often observed prices going up and down', and that this price volatility leaves EV-Co vulnerable due to current low production levels and low financial reserves.

With regard to the quantities of items purchased, Motor-Co is infrequently sourcing low quantities from Components-Co and Thermosensor-Co, and accounts for only a small percentage of their total sales. This makes Motor-Co vulnerable during production ramp-up due to its current weak buying power. By contrast, other large customers who buy from Components-Co and Thermosensor-Co are more important than Motor-Co, as they place regular high-volume orders. In turn, Components-Co and Thermosensor-Co are dependent on their other major customers that account for the majority of their sales. Any increased demand from these more significant and powerful customers could have a detrimental effect on supply to Motor-Co, and therefore indirectly on EV-Co, who have lower buying power and a lower priority order fulfilment rating.

Another concerning issue for EV-Co is the existence of a skills deficit that can lead to a dependence on human resources from other organisations. The Founder and Director of EV-Co stated that, 'the workforce will need to scale-up to cope with new production levels, but a workforce with the right skills can be hard to find, especially in key, emerging and sought-after areas, such as fuel cells, hydrogen and EV drivetrain technologies'. Chassis-Co, Components-Co and Castings-Co have also indicated a lack of skilled machinists who are able to make and/or modify metal parts, demonstrating an overall skills shortage in this supply chain. 


\subsubsection{Supplier substitutability}

EV-Co's tier one and tier two suppliers rely on single suppliers (i.e. sole sources), who in turn have long lead-times and high risks, as components and materials are purchased from non-UK suppliers positioned around the world. For example, a three to four month leadtime is needed for Components-Co to deliver necessary quantities to Motor-Co. Likewise, delivery times for magnets to be shipped to Rotor-Co and Encoder-Co, from the Far East to the UK, are 12-14 weeks and six weeks, respectively. All eight companies in this study follow a single-sourcing strategy, which means that, 'supplier control in bargaining is high and there are limited opportunities for lowering the price' (Founder and Director, EV-Co). Single sourcing is therefore undesirable, but unavoidable, in EV-Co's current modus operandi and is further exacerbated by high switching costs and risks in the wider business environment.

Another constraining factor was found to be the existing production processes and capabilities of suppliers. For example, Chassis-Co are currently, 'limited to 5000 cars per year, which is another constraint in production ramp-up' (Founder and Director, EVCo), and Motor-Co currently needs, 'three hours to produce one unit' (i.e. one motor), which is too long. Hence, if Chassis-Co and Motor-Co are to enable EV-Co to produce 30,000 units, major changes need to be made to their current processes, capacities and facilities. Each of these suppliers will have to seek to minimise production lead-times and/or significantly increase their production capacity. The alternative for EV-Co is to change supplier and experience high risk and switching costs.

\subsubsection{Discretion over resources.}


With respect to discretion over resources, geographical and political risk and increased competition have led to resource dependence. For critical City-Car components, such as magnets, fuel cells and thermo-sensors, EV-Co and Motor-Co must collaborate with international partners from the USA, Canada and China, creating high asset specificity dependence for their essential resources and capabilities (Espino-Rodríguez et al., 2008; Lonsdale, 2001). Also, for example, Rotor-Co supplies the magnet, a critical scarce natural resource that cannot be accessed easily from anywhere but China. According to Rotor-Co's Assistant Sales Manager, 'Raw material costs are forecast to increase over the coming 18 months, due to demand and legislation changes in China'. ThermosensorCo also experience volatility when purchasing components for the temperature sensor from three suppliers who are based in China. Also, companies from the EV sector compete not just with other EV companies, but also with traditional incumbent organisations in the automotive industry for generic components. This competition creates even lower relative discretionary power for new small EV manufacturers. Some empirical evidence, in the form of pertinent selected interviewee quotes, in respect to such RDT factors in this EV supply chain, is given in Table 2.

-Insert Table 2 Approximately Here

\subsection{Strategies used to minimise/overcome resource dependency risks.}

\subsubsection{Buffering strategies}

Buffering strategies entail holding inventories, or altering the structure and goals of firms, in order that a resource will no longer be a critical stock-out (Pfeffer and Salancik, 1978). 
For example, Motor-Co and Encoder-Co both keep high inventory levels of castings and magnets, respectively. This buffering reduces the chance of running out of a product. However, this strategy is not always possible to implement as resources such as dysprosium have a high cost, and the price is volatile, making them too risky to stockpile. Similarly, Rotor-Co has a transactional arms-length relationship with a Chinese supplier, and a low inventory is kept. As the Assistant Sales Manager of Rotor-Co states, 'We keep low inventory for parts to keep the cost down. Decisions regarding stock levels are based only on local information ... We don't have a global forecasting system to follow spot prices'.

In respect to buffering strategies, another practice for production ramp-up is to increase production flexibility in terms of facilities and capabilities. The founder and director of EV-Co stated that, 'Many of our smaller suppliers will not be able to grow beyond 50-100 units per year - (e.g. bodywork) unless they decide to invest and grow with us'. For example, Chassis-Co, Components-Co and Rotor-Co are SMEs that can currently only support production volumes of less than 1,000 units per year and cannot support volumes above. Yet, EV-Co has a target of producing up to 30,000 units per year. Without absolute capacity growth across the supply chain, particularly in the UK suppliers, extreme flexibility has to be built into supply chain-based production systems. In the short-term, tier one and tier two suppliers could implement a second production shift and in the longer term invest in new plant facilities. However, the Founder and Director of EV-Co stated that if more volume was available, 'we should not necessarily be obliged or have to fulfil all of it, but we could look to collaborate with other companies such as Google and Tesla for volume to help fill it'. This suggests that some critical supply chain echelons may have to be buffered to encourage EV supply chains to grow. Furthermore, the Finance Director and General Manager of Rotor-Co highlighted that 'if 
there is a need for more parts, then we'll ask our parent company in India to support us'. This demonstrates that trust and reciprocity in supply-chain relationships is (i) worldwide; (ii) essential but not obligatory; and (iii) that opportunism is likely to prevail over loyalty. If buffering is to be used effectively it needs to be reciprocal, and used in trusted partnerships, supported by wider governmental interventions.

In this case, process technology levels, and process integration levels, were also found to be low, because material resource planning / enterprise resource planning (MRP / ERP) systems were not used by EV-Co, Chassis-Co or Rotor-Co. Significantly, EV-Co and Rotor-Co have plans to invest in those systems to improve the management of dependence for the future. This investment would be via Motor-Co (sitting in the firsttier between them), who plan to upgrade their 'ERP system to assist the purchasing team to take ownership of the management of the motor production as we will then be able to have fuller visibility of our components suppliers' activities and act on behalf of our end customer' (Director, Motor-Co). Without such systems, it will be more challenging to implement innovative effective buffering strategies to aid ramp-up plans. Additional empirical evidence, in the form of interviewee quotes, in respect to RDT buffering practice, as used by EV-Co and its suppliers, is provided in Table 3.

-Insert Table 3 Approximately Here

\subsubsection{Bridging strategies}

EV-Co's relationships with suppliers range from arm's length relationships for relative commodities to more co-operative relationships for more customised parts. Furthermore, purchases predominantly made by Motor-Co, Castings-Co, Components-Co and RotorCo are price driven. However, in the future, EV-Co plan to pursue longer-term contracts 
that establish thresholds for volumes and prices over an extended period which may, 'bring together managerial personnel from different firms and contribute to a perception of common interests between the interdependent entities' (Jaffee, 2010, p. 11).

Moreover, in the future, EV-Co and Motor-Co intend to involve their suppliers earlier on in the product design process. Thus, component and material suppliers are able to advise manufacturing companies in respect of design and production specifications, and minimise cost without adversely affecting product quality. Specifically, Chassis-Co, Components-Co and Rotor-Co need to be increasingly involved in the conceptual definition stage of Motor-Co’s engineering design.

Additional empirical evidence, in the form of interviewee quotes in respect of RDT bridging strategies, as used by EV-Co and its suppliers, is provided in Table 3. The above empirical exploratory narrative in Sections 4.2 and 4.3 , based on RDT, is summarised into a conceptual framework in Figure 3.

\section{Empirical findings: Explanation}

\subsection{Factors that determine the level of dependence during production ramp-up}

The PrOH modelling captures socio-economic-political factors, such as taxation, car sharing practice, emissions / environmental legislation, which act upon post-ICE dominated era transportation systems. These factors are likely to bring dramatic dynamic disruption to the automotive industry, and require companies to develop new operating characteristics. These factors help to understand changes and dependencies in the EV- 
Co's supply chain in a wider social, economic and political context in accordance with RDT (c.f. RQ1).

This study has also identified the following operating factors that affect the level of dependence between niche manufacturing companies and their suppliers' resources during ramp-up activities: cost/price; quantity; skills; number of suppliers; switching costs and capabilities; competition; and geographical and political risks. This study confirms previous research findings (e.g. Caniëls and Gelderman, 2005) in respect of cost/price, quantity, number of suppliers and switching costs. Additionally this study has identified new factors, such as: (i) skills, (ii) capabilities, (iii) geographical and, (iv) political risks.

The failure to safeguard against critical resource volume dependencies during production ramp-up can hinder large-scale production ramp-up. For example, lithium-ion batteries are particularly vulnerable. In light of these issues, BMW announced the signing of a ten-year contract to secure the supply of cobalt and lithium for EV batteries (Lambert, 2018). In this volatile business environment, small companies, such as EV-Co, must be creative to build strong relationships with suppliers of cobalt (and rare earth elements) and divert some supply away from traditional OEMs (Hull and Deaux, 2016; Petersen, 2017).

5.2. Supply chain strategies to manage resource dependencies during production rampup

Regarding the second research question (c.f. RQ2), concerning strategies used by niche manufacturing companies to manage their resource dependencies during production ramp-up in an EV supply chain, this study found that companies apply a mix of 'buffering' and 'bridging' strategies. 
In the case of buffering strategies, safety stocks are preferred for magnets, while they are avoided for raw material resources such as dysprosium (due to price fluctuations). This is particularly the case for Motor-Co and Encoder-Co, both of whom use buffering strategies in response to demand volatility and/or production ramp-up. In a similar vein, EV-Co is beginning to use licencing agreements to manufacture with suppliers such as Motor-Co, who are building a new 'contract production' facility, and Chassis-Co, who have plans to increase production capacity at existing facilities to accommodate new increased demand.

Concerning bridging strategies, EV-Co originally chose its suppliers on a job-byjob basis, however, as production volumes increase, both EV-Co and its suppliers must work together more closely, to better manage and forecast their resource dependencies. According to Dharmani et al. (2013), developing close relationship with suppliers is a key part of capacity-change management. Bridging strategies may be particularly salient in the case of critical resources where the discretion over any resource is relatively low. For example, the purchase of components made from rare earth elements from China, and magnet-based resources purchased by Rotor-Co, would benefit from more effective bridging strategies to help elevate potential production ramp-up constraints.

\subsection{New insights into buyer-supplier relationships in the EV sector}

A remarkable and unusual finding of this research is that EV-Co (an SME) works closely with its supplier Motor-Co (a medium-to-large organisation) based on a supplier-led collaboration; Motor-Co orchestrates and manages EV-Co's entire supply chain, without exploiting its high dependency (Tangpong et al., 2015, p. 163). This supplier-led development initiative is in direct contrast with the traditional practice in the automotive industry, which is dominated by buyer-led collaborations and exploitation of smaller 
companies by the larger ones. Successful R\&D collaborations like this, as highlighted by this new empirical case, are especially critical in the early integration of suppliers and new EV OEMs in the new product development process (Binder et al., 2008; Kähkönen et al., 2015, p. 153). This is line with Mena et al. (2013) who found that as dependencies shift to the upstream part of the supply chain (e.g. raw materials suppliers), upstream companies become more powerful, and need to help develop new routes to market for their materials and components. As this paper's original research demonstrates, this means that upstream companies such as Motor-Co will actively help to develop and support the growth of new EV OEMs.

To put it another way, EV-Co as a start-up company, which focuses on R\&D of end-user products (e.g. cars) and services (mobility services), can open up significant new markets for its upstream (raw material) suppliers, who may be less end-user R\&D focused and more focused on high-volume production R\&D. Thus, niche EV manufacturers can help suppliers to explore and exploit new market opportunities, use resources in their supply chain more innovatively, and through effective bridging and buffering strategies, and production ramp-up plans, improve their overall supply chain's performance (Altmann and Meil, 1992).

EV-Co has specific plans to partner with one or more other contract production companies, in addition to Motor-Co, through buffering strategies, as EV-Co does not plan to set up any manufacturing capability of its own. This practice is also common in other industries, such as pharmaceuticals and electronics, where so-called 'fabless' start-up companies focus on their core $\mathrm{R} \& \mathrm{D}$ competencies and outsource their production to 'foundry-like' contract-production companies, who may also be partly responsible for the co-marketing of end products (Wagner et al., 2017). 
EV-Co also has plans to mitigate high dependence on its suppliers through bridging strategies to improve relational capital and safeguard against uncertainties in the supply chain. The size of companies sought by EV-Co will be predicated by EV-Co's ramp-up ambitions. Larger ramp-up ambitions for EV-Co means bridging to larger companies with higher production capacities. These findings and plans are consistent with the empirical studies by Bode et al. (2011) and Su et al. (2014), who observed that when dependence on suppliers is high, bridging strategies are often employed.

\section{Conclusions and implications}

In the emerging EV sector, companies are developing new strategies and business models to respond to issues of dependence. The literature highlights the need to explore dependencies through better planning and execution of production ramp-up. Building on this, this study has examined a niche vehicle manufacturer and its suppliers of drivetrain related components, such as the motor, battery, fuel cells and electronic control units. This qualitative multi-tier supply chain study is based on RDT to gain insights into how dependencies are formed during the ramp-up of production activities, and how strategies are used to minimise resource dependencies (e.g. early supplier involvement) in respect to capabilities, supply relationships and volume flows.

\subsection{Research Implications}

Our findings offer a new perspective on supply chain production ramp-up in the EV sector. This research is one of the first empirical studies addressing changing dependencies, which arise during supply chain production ramp-up in the EV sector (Li et al., 2014; Pazirandeh and Herlin, 2014), by applying RDT. There are three main implications stemming from this research. 
The first implication is that this study considers all three factors that determine dependence levels: importance of the resource; supplier substitutability; and discretion exercised over resources. This study further extends RDT by identifying sub-factors that determine dependence levels such as: skills; capabilities; and geographical and political risks.

The second implication relates to the level of dependence and supplier involvement. Our research shows that early involvement and relationship-specific investments by the supplier (i.e. Motor-Co), in the new-product development of City-Car, increased buyer-supplier inter-dependence. Therefore, this study adds to the existing body of knowledge regarding the dependence of buyers on their suppliers. For example, Kähkönen et al. (2015) also found early supplier involvement increases the buyer's dependence on its suppliers. However, Kähkönen et al. 's study was based on a single company-level survey sample and did not investigate the phenomenon in-depth. Neither did that study provide a rich understanding in a multi-tier case study.

The third implication relates to supply chain strategies employed. This study has found that two main supply chain strategies (i.e. buffering and bridging) can be successfully used to manage dependencies during the production ramp-up. This is in line with the research of Su et al. (2014) and partially in line with Bode et al. (2011), the latter of whom advocate only bridging strategies. Common buffering strategies found in this study are capacity sharing reciprocation, and a change towards mutually beneficial production planning. Meanwhile, bridging strategies found through this study include the strengthening of strategic partnerships and IT collaboration. As industry clock-speed is expected to increase in the EV sector, due to quickening technological changes (i.e. new fuel technology and batteries), an appropriate blend of buffering and bridging strategies will make firms, especially SMEs, more resilient to dynamic change. 


\subsection{Managerial Implications}

This paper focused on resource dependencies in the production of EV vehicles, which differ from conventional vehicles. Whereas innovation in the conventional automotive industry is mainly driven only by a few large organisations, mainly OEMs and large tier one suppliers, innovation in the EV industry can come from both large and small companies. More specifically, SMEs are playing a crucial role as either suppliers and/or vehicle manufacturers. Moreover, the power is shifted upward in the supply chain away from conventional vehicle manufacturers, and away from generic automotive companies, towards specialist newcomer suppliers (Bierau et al., 2015). It is expected that around eight million EVs will be on UK roads by 2040 and a long-term transformation of the automotive industry will be needed (Fojcik, 2013). Supply chain managers should be aware of the following related findings from this study.

A lack of certain critical capabilities and capacities amongst domestic UK suppliers has been identified when put into the context of global EV supply chains. These include uncompetitive unit costs, lack of some technical capabilities, and lack of qualified suppliers with sufficient capacity (APC, 2016; Automotive Council UK, 2015).

Supply chain, logistics and purchasing managers should gain a better understanding of resource dependencies, which become set during planning and execution of production ramp-up, and which are difficult to cost-effectively diverge from later on. As stronger buyer-supplier relationships are critical for both niche and large EV OEMs, and their UK suppliers, supply chain managers must become more adept at blending bridging and buffering strategies to help the EV sector to grow. 
Buyers are recommended to involve their suppliers early on in EV product development, and process design, and incentivise smaller suppliers to become more motivated and increasingly involved in production ramp-up. An additional four billion GBP of annual component purchasing from UK suppliers has been recognised by UK car manufacturers as necessary in order to reach a critical volume. However, OEMs are not always able to purchase their components from local suppliers, as many report that their plants run close to, or at, full capacity, and they have little flexibility (Henry, 2015). This suggests that a more sophisticated blend of bridging and buffering strategies is needed.

Lastly, the EV industry is evolving rapidly in terms of embracing new technologies. Supply chain managers should consider commissioning new training programmes to train purchasers and/or technicians with the skills to negotiate creatively with suppliers of batteries, electric motors, and advanced computer and electrical system development (Roche, 2015).

\subsection{Limitations and Future Research}

This case study primarily focuses on the supply chain of a small UK-based EV manufacturer. Therefore, results may not be directly transferable to other sectors and/or countries.

Future research could explore and compare similar production ramp-up resource dependencies strategies in other EV companies, who have already achieved mature and established supply chains, in a retrospective study. For example, by using RDT, a future study could explain how Tesla made a doubly competitive move when they acquired Grohmann Engineering (a German automation company) to positively accelerate their own vehicle production. This was doubly competitive, because, in doing so, they may 
have also negatively impacted upon Mercedes and BMW, as Mercedes and BMW were both dependent on Grohmann's equipment to build their own EVs (Miller, 2017).

Future research could also collect further quantitative data based on these findings to investigate the effects of different resource dependency types and levels on bridging and buffering strategies used during supply chain ramp-up. Such an investigation could be achieved through the use of dynamic simulation (based on Figure 2) or structural equation modelling approaches (based on Figure 3).

\section{Acknowledgements}

The authors would like to thank the Niche Vehicle Network, which is part of the Advanced Propulsion Centre UK, for financially supporting this research. The authors would also like to thank all the companies and people who took part in the empirical research. 


\section{References}

Almgren, H. (2000), "Pilot production and manufacturing start-up: The case of Volvo S80”, International Journal of Production Research, Vol. 38, No. 17, pp. 4577-4588.

Andersen, M., Dauner, T., Lang, N. and Palme, T. (2016), "What automakers can learn from the Tesla phenomenon", available at:

https://www.bcgperspectives.com/content/articles/automotive-what-automakers-canlearn-from-tesla-phenomenon/ (accessed 15 December 2016).

Advanced Propulsion Centre (APC) (2016), "Low carbon automotive propulsion technologies", available at:

http://www.apcuk.co.uk/wp-content/uploads/2016/07/APC_2016CapabilityReport.pdf (accessed 26 April 2017).

Altmann, N., Kohler, C. and Meil, P. (1992), Technology and Work in German Industry. Routledge Library Editions, New York.

Automotive Council UK. (2015), "Growing the automotive supply chain the opportunity ahead", available at:

http://www.automotivecouncil.co.uk/wp-content/uploads/2015/03/Growing-the-UKauto-supply-chain-March-2015.pdf (accessed 15 April 2017).

Barratt, M., Choi, T.Y., and Li, M. (2011), "Qualitative case studies in operations management: trends, research outcomes, and future research implications", Journal of Operations Management. Vol. 29, pp. 329-342.

Bierau, F., Perlo, P., Müller, B., Gomez, A. Coosemans, T. and Meyer, G. (2015), "Opportunities for European SMEs in Global Electric Vehicle Supply Chains in Europe and Beyond", in Schulze, T., Müller, B. and Meyer, G. Advanced Microsystems for Automotive Applications 2015, Smart Systems for Green and Automated Driving, Springer International Publishing, Switzerland, pp. 223-235.

Binder, M., Gust, P., and Clegg, B. (2008), "The importance of collaborative frontloading in automotive supply networks", Journal of Manufacturing Technology Management, Vol. 19, No. 3, pp. 315-333.

Bode, C., Petersen, K. and Ellram, L. (2011), "Understanding Responses to supply chain disruptions: insights from information processing and resource dependence perspectives", Academy of Management Journal. Vol. 54, No. 4, pp. 833-856.

Caniëls, M.C.J. and Gelderman, C.J. (2005), "Purchasing strategies in the Kraljic matrixA power and dependence perspective", Journal of purchasing and supply management, Vol. 11, pp. 141-155.

Casciaro, T. and Piskorski, M.J. (2005), "Power imbalance and inter-organizational relations: resource dependence theory revisited", Academy of Management, pp. 1-57.

Choudhari, S., Adil, G. and Ananthakumar, U. (2012), "Exploratory case studies on manufacturing decision areas in the job production system", International Journal of Operations and Production Management, Vol. 32, No. 11, pp. 1337-1361.

Christensen, I. and Karlsson, C. (2016), "Inter-organisational coordination in Ramp-up execution - a multiple case study", The 23rd International Annual EurOMA Conference, Trondheim, Norway, 17 June - 22 June 2016. 
Christensen, I. and Rymaszewska, A. (2016), "Lean application to manufacturing rampup: a conceptual approach", Quality Management Journal, American Society for Quality, Inc., Vol. 23, No. 1, pp. 45-54.

Clark, K., and Fujimoto, T. (1991), Product development performance: strategy, organization, and management in the world auto industry, Harvard Business School Press, Boston, MA.

Clegg B.T. (2006), "Building a holarchy using business Process Orientated Holonic (PrOH) Modeling", IEEE Systems, Man and Cybernetics: Part A. Vol. 37, No. 1. pp. 23-40.

Clegg, B.T. (2018), "Perceptions of growth-impeding constraints acting upon SMEs' operations and the identification and use of transitionary paths to elevate them", International Journal of Operations \& Production Management, Vol. 38, No. 3, pp. 756-783,

Clegg, B.T., and Shaw, D. (2008), "Using Process-Orientated Holonic (PrOH) Modelling to increase understanding of information systems", Information Systems Journal. Vol. 18 , pp. $447-477$

Creswell, J.W., and Plano Clark, V.L. (2007), Designing and Conducting Mixed Methods Research, Sage, Thousand Oaks, CA.

Cuffaro, D., Zaksenberg, I. and Oliver, G. (2013), The Industrial Design Reference and Specification Book: Everything Industrial Designers Need to Know Every Day, Rockport Publishers, Gloucester, MA.

Dharmani, S., Anand, D. and Demirci, M. (2013), "Shifting gear capacity management in the automotive industry", available at:

http://www.ey.com/Publication/vwLUAssets/EY-shifting-gear-capacity-managementin-the-automotiveindustry/\$FILE/1002043\%20SP1600\%20Advisory\%20Supply\%20Chain\%20Whitep aper_V15_LR\%20pdf\%20-\%20Updated.pdf (accessed 30 August 2017).

Edmondson, A.C., and McManus, S.E. (2007), "Methodological fit in management field research", Academy of Management Review, Vol. 32, pp. 1246-1264.

Eisenhardt, K.M. (1989), "Building Theories from Case Study Research”, Academy of Management Review, Vol. 14, No. 4, pp. 532-550.

Elstner, S., and Krause, D. (2014), "Methodical approach for consideration of ramp-up risks in the product development of complex products". Second International Conference on Ramp-Up Management, Vol. 20, pp. 20-25.

Espino-Rodríguez, T., Lai, P. and Baum, T. (2008). "Asset specificity in make or buy decisions for service operations: an empirical application in the Scottish hotel sector", International Journal of Service Industry Management, Vol. 19, No. 1, pp. 111-133.

Filla, P. and Klingebiel, K. (2014), "Risk profiles for the pre-series logistics in automotive ramp-up processes", in CIRP 2014. 2nd International Conference on Ramp-Up Management, Procedia CIRP, Vol. 20, pp. $44-49$.

Fojcik, T.M. (2013), "Exploitation, exploration and the ambidextrous design choice in the transition to electric vehicles: An analysis of small and medium-sized automotive suppliers in Germany", International Journal of Automotive Technology and Management, Vol. 13, No. 4, pp. 354-371. 
Glock, C. H., and Grosse, E. H. (2015), "Decision support models for production rampup: a systematic literature review", International Journal of Production Research, Vol. 53, No. 21, pp. 6637-6651.

Günther, H.O., Kannegiesser, M., and Autenrieb, N. (2015), "The role of electric vehicles for supply chain sustainability in the automotive industry", Journal of Cleaner Production, Vol. 90, pp. 220-233.

Hawkins, T.R., Singh, B., Majeau-Bettez, G., and Strømman, A.H. (2012), "Comparative environmental life cycle assessment of conventional and electric vehicles", Journal of Industrial Ecology, Vol. 17, No. 1, pp. 158-160.

Held, T. (2010), "Managing production ramp-ups in the European automotive supply chain - the supplier's view", in Blecker, T., Kersten, W. and Lüthje, C., Innovative process optimization methods in logistics: emerging trends, concepts and technologies, Erich Schmidt Verlag, Berlin, pp. 99-112.

Hendrickson, T.P., Kavvada, O., Shah, N., Sathre, R., and Scown, C. (2015), "Life-cycle implications and supply chain logistics of electric vehicle battery recycling in California", Environmental Research Letters, Vol. 10, No. 1, pp. 1-10.

Henry, I. (2015), "Long-term forecast paper for The Society of Motor Manufacturers and Traders (SMMT)", available at:

https://www.smmt.co.uk/wp-content/uploads/sites/2/AutoAnalysis-report-the-future-ofUK-automotive-manufactuing-October-2015.pdf (accessed 4 May 2017).

Hirschheim, R., Heinzl, A. and Dibbern, J. (2009), Information Systems Outsourcing: Enduring Themes, New Perspectives and Global Challenges, Springer International Publishing, Switzerland

Hofmann, H., Schleper, M.C. and Blome, C. (2015), "Conflict minerals and supply chain due diligence: an exploratory study of multi-tier supply chains", Journal of Business Ethics, Vol. 147, No. 1, pp. 115-141.

Hull, D. and Deaux, J. (2016), "Elon Musk is squaring off against China for the future of Tesla", available at: https://www.bloomberg.com/news/articles/2016-06-23/elonmusk-is-squaring-off-against-china-for-the-future-of-tesla (accessed 7 May 2017).

IEA (2017), "Global EV outlook 2017 two million and counting", available at: https://www.iea.org/publications/freepublications/publication/GlobalEVOutlook2017 .pdf (accessed 13 February 2018).

Jaffee, D. (2010), "Kinks in the intermodal supply chain: longshore workers and drayage drivers", Society for the Advancement of Socio-Economics, Philadelphia, pp. 1-42.

Juan, A., Mendez C., Faulin J., de Armas J., and Grasman S. (2016), "Electric vehicles in logistics and transportation: a survey on emerging environmental, strategic, and operational challenges", Energies, Vol. 9, No. 2, pp. 1-21.

Kalaitzi, D., Matopoulos, A., Bourlakis, M. and Tate, W. (2018), "Supply chain strategies in an era of natural resource scarcity", International Journal of Operations and Production Management, Vol. 38, Iss. 3, pp. 784-809.

Kam, K. (2016), “The catalyst for Tesla is production”, available at:

http://www.forbes.com/sites/kenkam/2016/06/17/the-catalyst-for-tesla-isproduction/\#a07d5db24dc4 (accessed 15 December 2016). 
Kähkönen , A., Lintukangas, K. and Hallikas, J. (2015), “Buyer's dependence in value creating supplier relationships", Supply Chain Management: An International Journal, Vol. 20, No. 2, pp. $151-162$.

Ketokivi, M., and Choi, T. (2014), "Renaissance of case research as a scientific method", Journal of Operations Management, Vol. 32, No. 5, pp. 232-240.

King, N. (2004), "Using interviews in qualitative research", in Cassell, C. and Symon, G. (Eds), Essential Guide to Qualitative Methods in Organizational Research, Sage, London, pp. 11-22

Klug, F. (2013), "How electric car manufacturing transforms automotive supply chains", in 20th International EurOMA Conference Proceedings, Dublin, Ireland.

Lambert, Douglas M., Ed. (2004), "Supply Chain Management: Processes, Partnerships, Performance", Supply Chain Management Institute, Sarasota, FL.

Lambert, F. (2018), "BMW is trying to secure a 10-year supply of cobalt and lithium for EV batteries", available at: https://electrek.co/2018/02/12/bmw-battery-electric-carsupply-cobalt-lithium/ (accessed 23 February 2018).

Leonardi. (2013), "The emergence of materiality within formal organizations", in P.R. Nicolini, A. Langley, and H. Tsoukas (Eds.) How Matter Matters: Objects, Artifacts and Materiality in Organization Studies, Oxford University Press, Oxford, pp. 142170.

Levina, N., and Vaast, E., (2005), "The emergence of boundary spanning competence in practice: implications for implementation and use of information systems", MIS Quarterly, Vol. 29, pp. 335-363.

Lonsdale, C. (2001), "Locked-in to supplier dominance: on the dangers of asset specificity for the outsourcing decision", Journal of Supply Chain Management, Vol. 37, No. 2, pp22-27.

Li, Y., Zhan, C., de Jong, M. and Lukszo, Z. (2015), "Business innovation and government regulation for the promotion of electric vehicle use: lessons from Shenzhen, China”, Journal of Cleaner Production, Vol. 134, pp. 371-383.

Li, H.H., Shi, Y.J., Gregory, M., and Tan. K. M. (2014), "Rapid production ramp-up capability: a collaborative supply network perspective", International Journal of Production Research, Vol. 52, No. 10, pp. 2999-3013.

Lilly, C. (2018), "Electric car market statistics", available at:

https://www.nextgreencar.com/electric-cars/statistics/ (accessed 19 September 2018).

Mena, C., Humphries A. and Choi T.Y. (2013), "Toward a theory of multi-tier supply chain management". Journal of Supply Chain Management, Vol. 49, No. 2, pp. 58-77.

Meznar, M. and Nigh, D. (1995), "Buffer or bridge? Environmental and organizational determinants of public affairs activities in American firms", The Academy of Management Journal, Vol. 38, No. 4, pp. 975-996.

Miles, M.B. and Huberman, A.M. (1994), Qualitative Data Analysis, Sage, Thousand Oaks, CA.

Miller, J.D. (2017), “Tesla cuts off BMW, Mercedes with key supplier acquisition”, available at: 
https://www.linkedin.com/pulse/tesla-cuts-off-bmw-mercedes-key-supplieracquisition-jd-miller (accessed 4 May 2017).

Niroomand, I., Kuzgunkaya, O. and Bulgak, A. (2012), "Impact of reconfiguration characteristics for capacity investment strategies in manufacturing systems", International Journal of Production Economics, Vol. 139, No. 1, pp. 288-301.

Paulraj, A., and Chen, I.J. (2007), "Environmental uncertainty and strategic supply management: A resource dependence perspective and performance implications", Journal of Supply Chain Management, Vol. 43, No. 3, pp. 29-42.

Pazirandeh, A. and Herlin, H. (2014), "Unfruitful cooperative purchasing: A case of humanitarian purchasing power", Journal of Humanitarian Logistics and Supply Chain Management, Vol. 4, No. 1, pp. 24-42.

Petersen, K.J., Handfield, R.B., Lawson, B. and Cousins, P.D. (2008), "Buyer dependency and relational capital formation: the mediating effect of socialization process and supplier integration", Journal of Supply Chain Management, Vol. 44 No. 4, pp. 53-65.

Petersen, J. (2017), “Cobalt: The Weak Link In Tesla's Supply Chain”, available at: https://seekingalpha.com/article/4061069-cobalt-weak-link-teslas-supply-chain (accessed 4 May 2017).

Pfeffer, J. and Salancik, G. R. (1978). The External Control of Organizations: A Resource Dependence Perspective. Harper and Row, New York.

Pfeffer, J., and Salancik, G. R. (2003), The External Control of Organizations: A Resource Dependence Perspective. Stanford University Press, California.

Rossini, M., Ciarapica, F., Matt, D, and Spena, R. (2016), “A Preliminary study on the changes in the Italian automotive supply chain for the introduction of electric vehicles", Journal of Industrial Engineering and Management, Vol. 9, No. 2, pp. 450486.

Roche, N., (2015). “The Future of Electric Cars", available at:

https://careers2030.cst.org/articles/future-electric-cars/ (accessed 4 May 2017).

Schuh, G., Kampker, B., Franzkoch, B., and Tuecks, G. (2005), "Implementation of a maturity measurement model for planning and monitoring of production ramp ups", Paper presented at the Third International Conference on Reconfigurable Manufacturing Systems, Ann Arbor, Michigan, USA.

Steinhilber, S., Wells, P., and Thankappan, S., (2013), "Socio-technical inertia: understanding the barriers to electric vehicles", Energy Policy, Vol. 60, pp. 531-539.

Su, F., Mao, J.Y, and Jarvenpaa, S.L. (2014), "How do IT outsourcing vendors respond to shocks in client demand? A resource dependence perspective", Journal of Information Technology, Vol. 29, No. 3, pp. 253-267.

Surbier, L., Alpan, G. and Blanco, E. (2014), “A comparative study on production rampup: state-of-the-art and new challenges", Production Planning and Control: The Management of Operations, Vol. 25, No. 15, pp. 1264-1286.

Tachizawa, E. M., and Wong, C. Y. (2014), "Towards a theory of multitier sustainable supply chains: a systematic literature review", Supply Chain Management: An International Journal, Vol. 19, No. 5/6, pp. 643-663. 
Tangpong, C., Michalisin, M., Traub, R. and Melcher, A. (2015), "A review of buyersupplier relationship typologies: progress, problems, and future directions", Journal of Business and Industrial Marketing, Vol. 30, No. 2, pp. 153-170.

Terwiesch, C., and Bohn, R. E. (2001), "Learning and process improvement during production ramp-up", International Journal of Production Economics, Vol. 70, No. 11, pp. 1-17.

Touboulic, A., Chicksand, D. and Walker, H. (2014), "Managing imbalanced supply chain relationships for sustainability: a power perspective", Decision Sciences, Vol. 45 , pp. $577-619$.

van Hoek, R. and Chapman, P. (2007), "How to move supply chain beyond cleaning up after new product development", Supply Chain Management: An International Journal, Vol. 12, No. 4, pp. 239-244.

Voss, C., (2009), "Case research in operations management”, in Karlsson C, Researching Operations Management, Routledge, London.

Voss, C., Tsikriktsis, N. and Frohlich, M. (2002), "Case research in operations management", International Journal of Operations and Production Management, Vol. 22, No. 2, pp. 195-219.

Wagner, M., Valls-Pasola, J. and Burger-Helmchen, T. (2017), The Global Management of Creativity (Routledge Studies in Global Competition). Routledge, New York.

Wilhelm, M.M., Blome, C., Bhakoo, V. and Paulraj, A. (2015), "Sustainability in multitier supply chains: understanding the double agency role of the first-tier supplier", Journal of Operations Management, Vol. 41, pp. 42-60.

World Economic forum (Weforum). (2017), "The Future of Electricity New Technologies Transforming the Grid Edge", available at:

http://www3.weforum.org/docs/WEF_Future_of_Electricity_2017.pdf (accessed 23 June 2017).

Yin, R. K. (2003), Case study research: Design and methods (3rd ed.). Thousand Oaks, Sage, CA. 
Appendix A: Template for building and reading $\mathrm{PrOH}$ models.

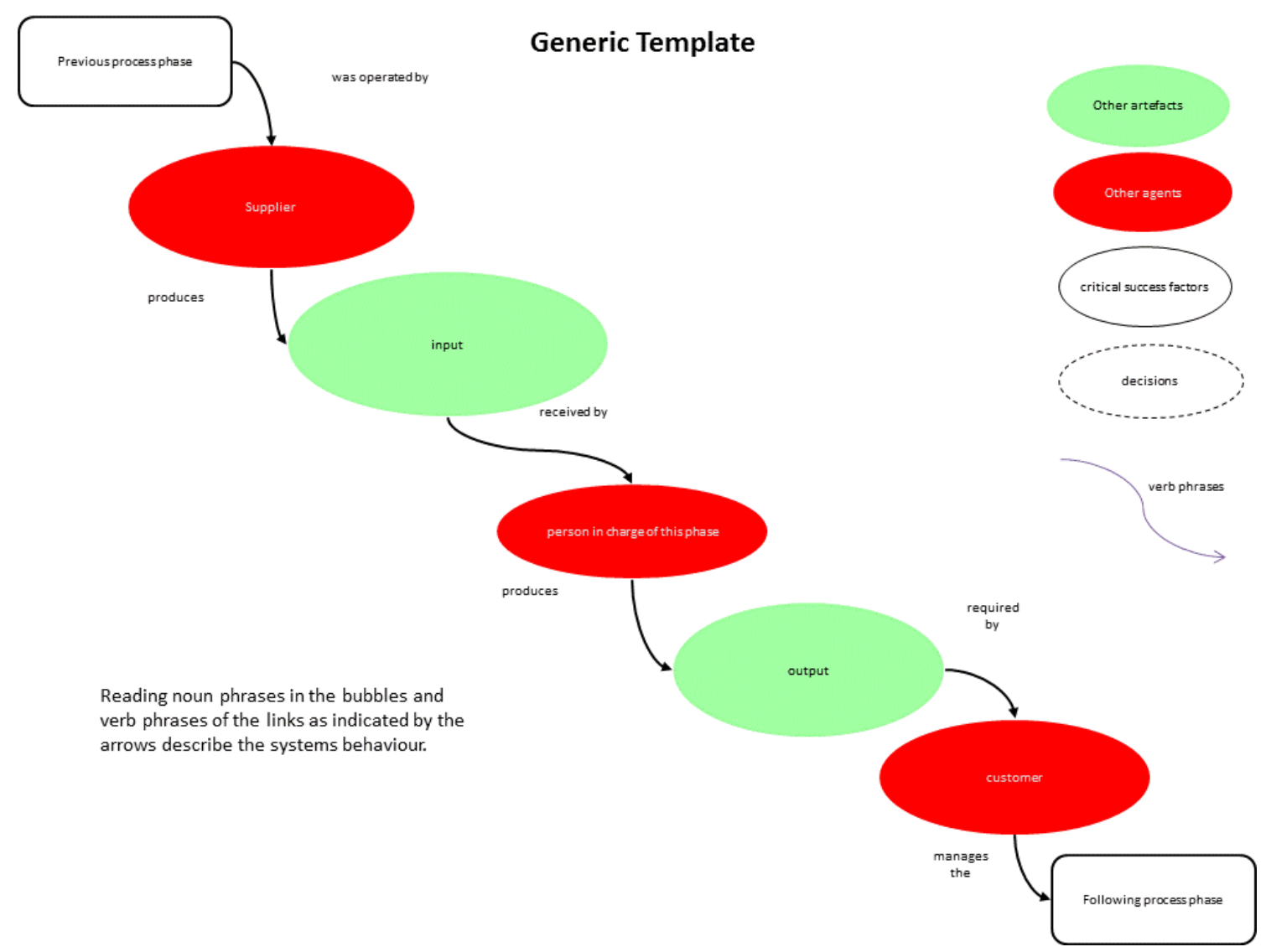


Table 1: Description of participating companies

\begin{tabular}{|c|c|c|c|c|c|c|}
\hline $\begin{array}{l}\text { Position in } \\
\text { the supply } \\
\text { chain }\end{array}$ & $\begin{array}{l}\text { Company } \\
\text { name }\end{array}$ & $\begin{array}{c}\text { No. of } \\
\text { employees }\end{array}$ & $\begin{array}{c}\text { Revenues } \\
\text { (f) }\end{array}$ & Description & $\begin{array}{c}\text { No. of } \\
\text { interviewees }\end{array}$ & $\begin{array}{c}\text { Interview } \\
\text { time and } \\
\text { observation }\end{array}$ \\
\hline $\begin{array}{l}\text { OEM - } \\
\text { focal firm }\end{array}$ & EV-Co & 7 & - & $\begin{array}{l}\mathrm{EV} \\
\text { manufacturer }\end{array}$ & $\begin{array}{l}2 \text { (founder \& } \\
\text { director and } \\
\text { mechanical } \\
\text { design engineer) }\end{array}$ & $\begin{array}{l}8 \text { hours }+ \\
2 \text { plant } \\
\text { tours }\end{array}$ \\
\hline \multirow[t]{2}{*}{$\begin{array}{l}\text { Tier 1 } \\
\text { suppliers }\end{array}$} & Motor-Co & 70 & $£ 4.6 \mathrm{~m}$ & $\begin{array}{l}\text { Axial flux } \\
\text { motor } \\
\text { manufacturer }\end{array}$ & 1 (director) & $\begin{array}{l}8 \text { hours }+ \\
1 \text { plant } \\
\text { tour }\end{array}$ \\
\hline & $\begin{array}{l}\text { Chassis- } \\
\text { Co }\end{array}$ & 150 & $£ 3 \mathrm{~m}$ & $\begin{array}{l}\text { Chassis } \\
\text { manufacturer }\end{array}$ & $\begin{array}{l}3 \text { (chief } \\
\text { engineer, senior } \\
\text { engineer and } \\
\text { logistics } \\
\text { manager) }\end{array}$ & $\begin{array}{l}4 \text { hours }+ \\
1 \text { plant } \\
\text { tour }\end{array}$ \\
\hline \multirow[t]{5}{*}{$\begin{array}{l}\text { Tier } 2 \\
\text { suppliers }\end{array}$} & $\begin{array}{l}\text { Castings- } \\
\text { Co }\end{array}$ & 25 & $£ 2.5 \mathrm{~m}$ & $\begin{array}{l}\text { Castings } \\
\text { manufacturer }\end{array}$ & $\begin{array}{l}2 \text { (technical } \\
\text { director and } \\
\text { quality assurance } \\
\text { manager) }\end{array}$ & $\begin{array}{l}2 \text { hours }+ \\
2 \text { plant } \\
\text { tours }\end{array}$ \\
\hline & $\begin{array}{l}\text { Componen } \\
\text { ts-Co }\end{array}$ & 23 & $£ 2 \mathrm{~m}$ & $\begin{array}{l}\text { Precision } \\
\text { components } \\
\text { manufacturer }\end{array}$ & 2 (directors) & $\begin{array}{l}4 \text { hours }+ \\
1 \text { plant } \\
\text { tour }\end{array}$ \\
\hline & Rotor-Co & 18 & $£ 2.6 \mathrm{~m}$ & $\begin{array}{l}\text { Rotor } \\
\text { manufacturer }\end{array}$ & $\begin{array}{l}2 \text { (finance } \\
\text { director and } \\
\text { general manager, } \\
\text { and assistant } \\
\text { sales manager) }\end{array}$ & $\begin{array}{l}2 \text { hours }+ \\
1 \text { plant } \\
\text { tour }\end{array}$ \\
\hline & $\begin{array}{l}\text { Thermose } \\
\text { nsor-Co }\end{array}$ & 131,000 & $£ 32.7 \mathrm{~b}$ & $\begin{array}{l}\text { Thermo } \\
\text { sensor } \\
\text { manufacturer }\end{array}$ & $\begin{array}{l}1 \text { (senior key } \\
\text { account } \\
\text { manager) }\end{array}$ & $\begin{array}{l}2 \text { hours }+ \\
1 \text { plant } \\
\text { tour }\end{array}$ \\
\hline & $\begin{array}{l}\text { Encoder- } \\
\text { Co }\end{array}$ & 4,000 & $£ 436.6 \mathrm{~m}$ & $\begin{array}{l}\text { Encoder } \\
\text { manufacturer }\end{array}$ & $\begin{array}{l}2 \text { (sales } \\
\text { managers) }\end{array}$ & $\begin{array}{l}4 \text { hours }+ \\
1 \text { plant } \\
\text { tour }\end{array}$ \\
\hline
\end{tabular}

Note: each plant tour lasted on average approximately two hours. 
Table 2: Resource dependence level in the EV sector

\begin{tabular}{|c|c|c|c|}
\hline $\begin{array}{l}\text { RDT factors } \\
\text { affecting }\end{array}$ & $\begin{array}{l}\text { EV sector } \\
\text { "elements" }\end{array}$ & Representative quotations & Interviewee \\
\hline \multirow{6}{*}{$\begin{array}{l}\text { (i) Importance } \\
\text { of the resource }\end{array}$} & Cost/ price & $\begin{array}{l}\text { "Another potential risk identified is } \\
\text { fluctuation on prices for some metals... } \\
\text { we cannot afford to hedge on our } \\
\text { purchases". }\end{array}$ & $\begin{array}{l}\text { Director 1, } \\
\text { Components-Co }\end{array}$ \\
\hline & & $\begin{array}{l}\text { "Magnets are an expensive part and } \\
\text { we have limited option where to buy } \\
\text { them". }\end{array}$ & Director, Motor-Co \\
\hline & & $\begin{array}{l}\text { "There are fluctuations in the price of } \\
\text { magnets ... we have no influence on } \\
\text { prices". }\end{array}$ & $\begin{array}{l}\text { Sales Manager 2, } \\
\text { Encoder-Co }\end{array}$ \\
\hline & Quantity & $\begin{array}{l}\text { "Majority of current parts } \\
\text { manufactured are low volume high end } \\
\text { precision, Motor-Co is looking } \\
\text { towards larger volume work to utilise } \\
\text { maximum machine hours... but firstly } \\
\text { we need larger orders". }\end{array}$ & $\begin{array}{l}\text { Director 2, } \\
\text { Components-Co }\end{array}$ \\
\hline & Skills & $\begin{array}{l}\text { "Managers lack specialist EV skills } \\
\text { that are necessary, we need better } \\
\text { people, but these cost more money" }\end{array}$ & $\begin{array}{l}\text { Founder and } \\
\text { Director, EV-Co }\end{array}$ \\
\hline & & $\begin{array}{l}\text { "There is lack of certain skills in order } \\
\text { to hire new people... this is a national } \\
\text { problem". }\end{array}$ & $\begin{array}{l}\text { Director 1, } \\
\text { Components-Co }\end{array}$ \\
\hline \multirow{3}{*}{$\begin{array}{l}\text { (ii) Supplier } \\
\text { substitutability }\end{array}$} & $\begin{array}{l}\text { Number of } \\
\text { suppliers }\end{array}$ & $\begin{array}{l}\text { "There is a lack of (aluminium tub) } \\
\text { chassis suppliers in the UK ... we need } \\
\text { a broader supply base for the next } \\
\text { generation of EVs". }\end{array}$ & $\begin{array}{l}\text { Founder and } \\
\text { Director, EV-Co }\end{array}$ \\
\hline & & $\begin{array}{l}\text { "There is a challenge to find other UK } \\
\text { suppliers for castings ... this takes time } \\
\text {... } 3^{\text {rd }} \text { party intervention would be } \\
\text { useful to help broker these } \\
\text { relationships". }\end{array}$ & Director Motor-Co \\
\hline & $\begin{array}{l}\text { Switching } \\
\text { costs and } \\
\text { capabilities }\end{array}$ & $\begin{array}{l}\text { "We have to stay with the current } \\
\text { supplier for the chassis due to cost and } \\
\text { complexity of changing ... this makes it } \\
\text { difficult to make significant product } \\
\text { changes". }\end{array}$ & $\begin{array}{l}\text { Founder and } \\
\text { Director, EV-Co }\end{array}$ \\
\hline $\begin{array}{l}\text { (iii) Discretion over } \\
\text { the resource }\end{array}$ & Competition & $\begin{array}{l}\text { "For example, recently we have } \\
\text { bought parts from a certain supplier as } \\
\text { they had really low inventory ... we } \\
\text { risk using parts that become obsolete } \\
\text { too quickly, before the end product gets } \\
\text { to market". } \\
\text { "There was a delay in the } \\
\text { commissioning of the batch production } \\
\text { of the motor from one of our supplier's }\end{array}$ & $\begin{array}{l}\text { Founder and } \\
\text { Director, EV-Co }\end{array}$ \\
\hline
\end{tabular}




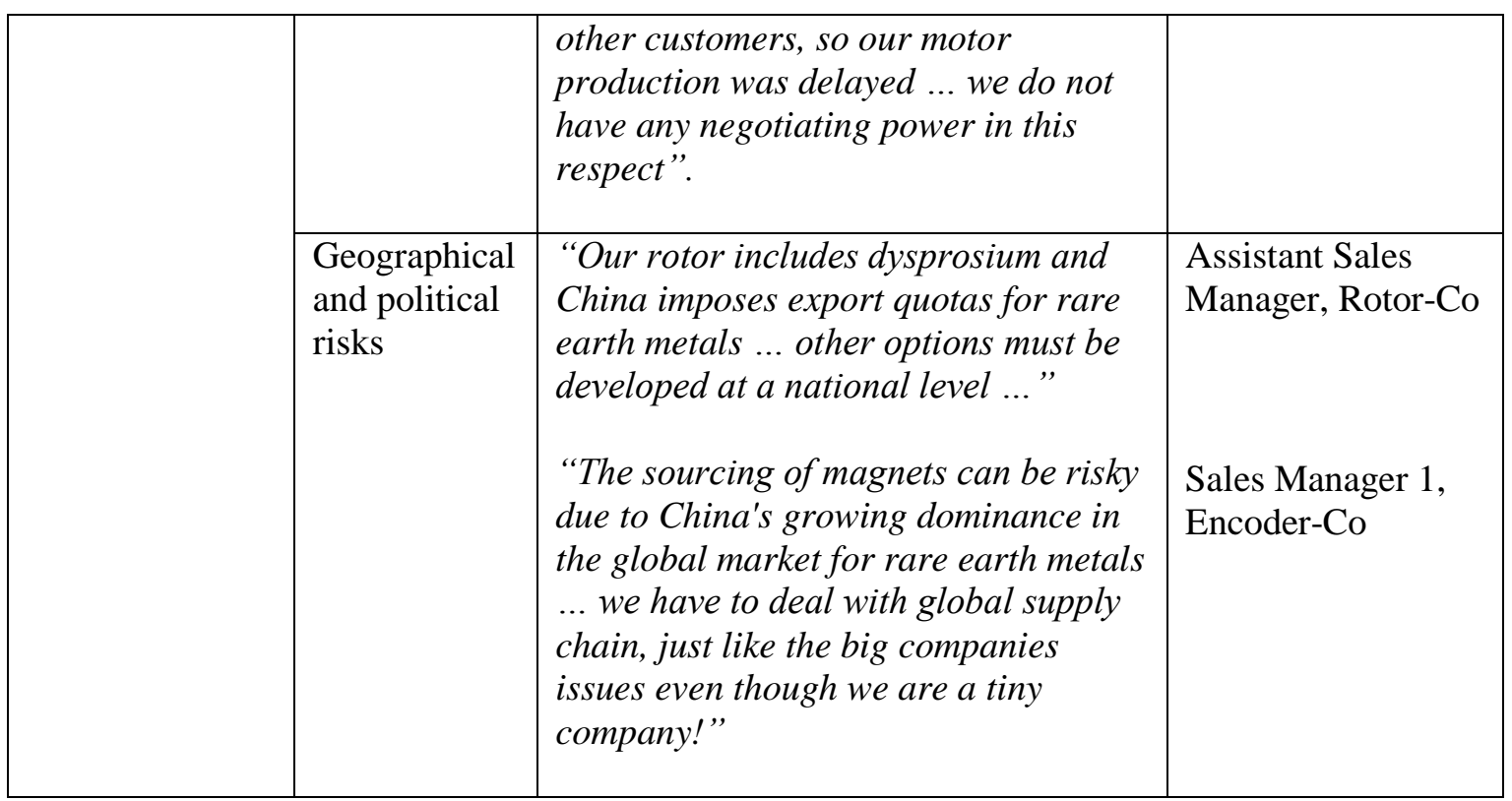


Table 3: Key Mechanisms and strategies to manage dependence levels in the EV sector

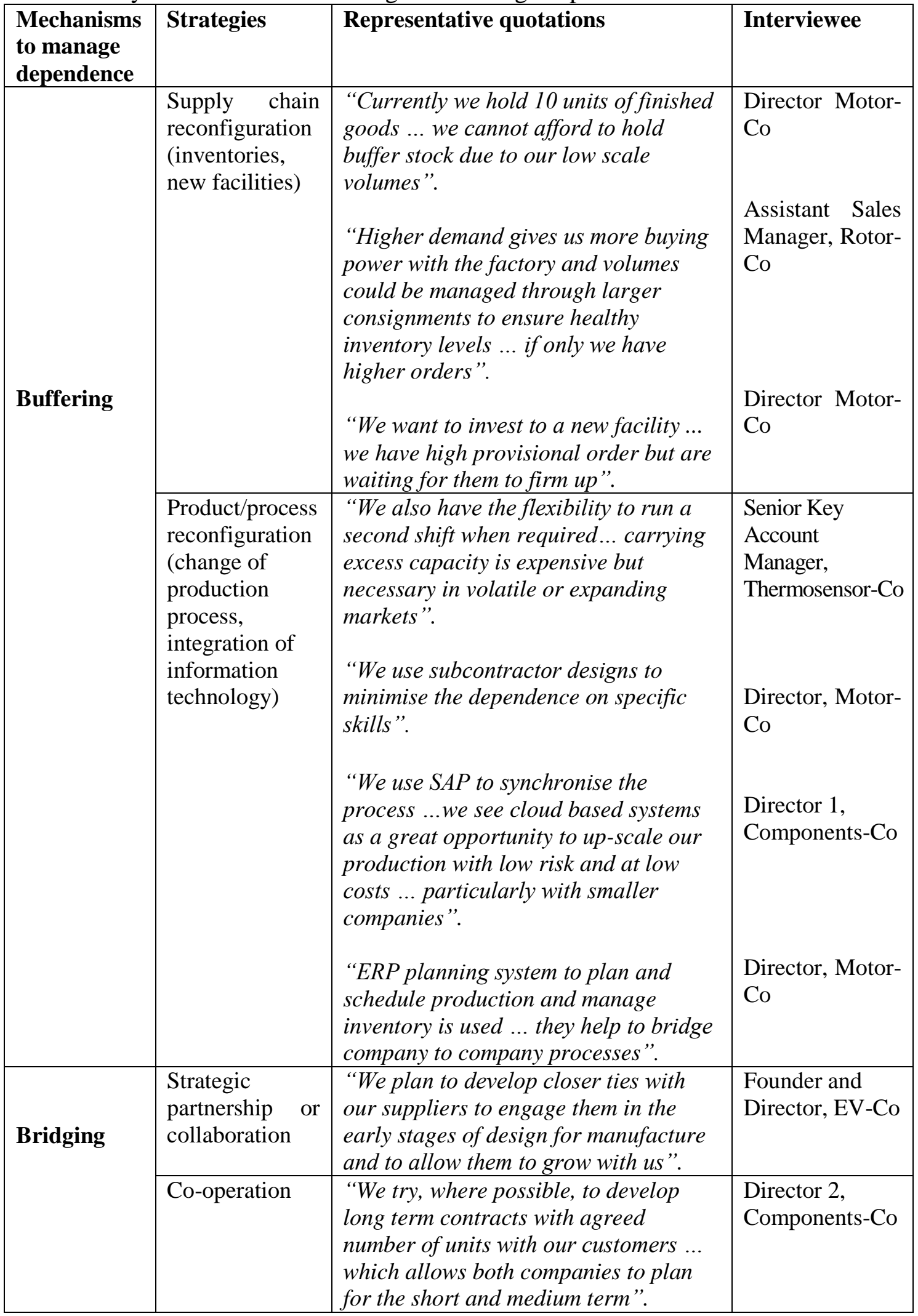


Figure 1: Supply chain tiers for EV-Co's City-Car drive train suppliers

Tier 2

Supplier

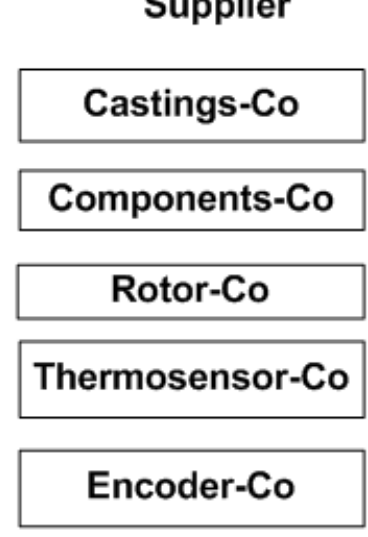

Tier 1

Supplier

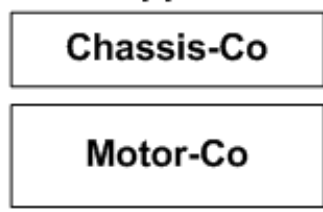

Hydrosystem-Co

Hydrogen-pressureregulator-Co

Fuel-cell-stack-Co

Battery-system-Co

Cells-Co

Motor-transm-Co

Comp(e.g. door handles, lights)-Co 
Figure 2: A PrOH model of dynamic systemic factors for forthcoming challenges in the automotive industry moving towards a post-ICE dominated era

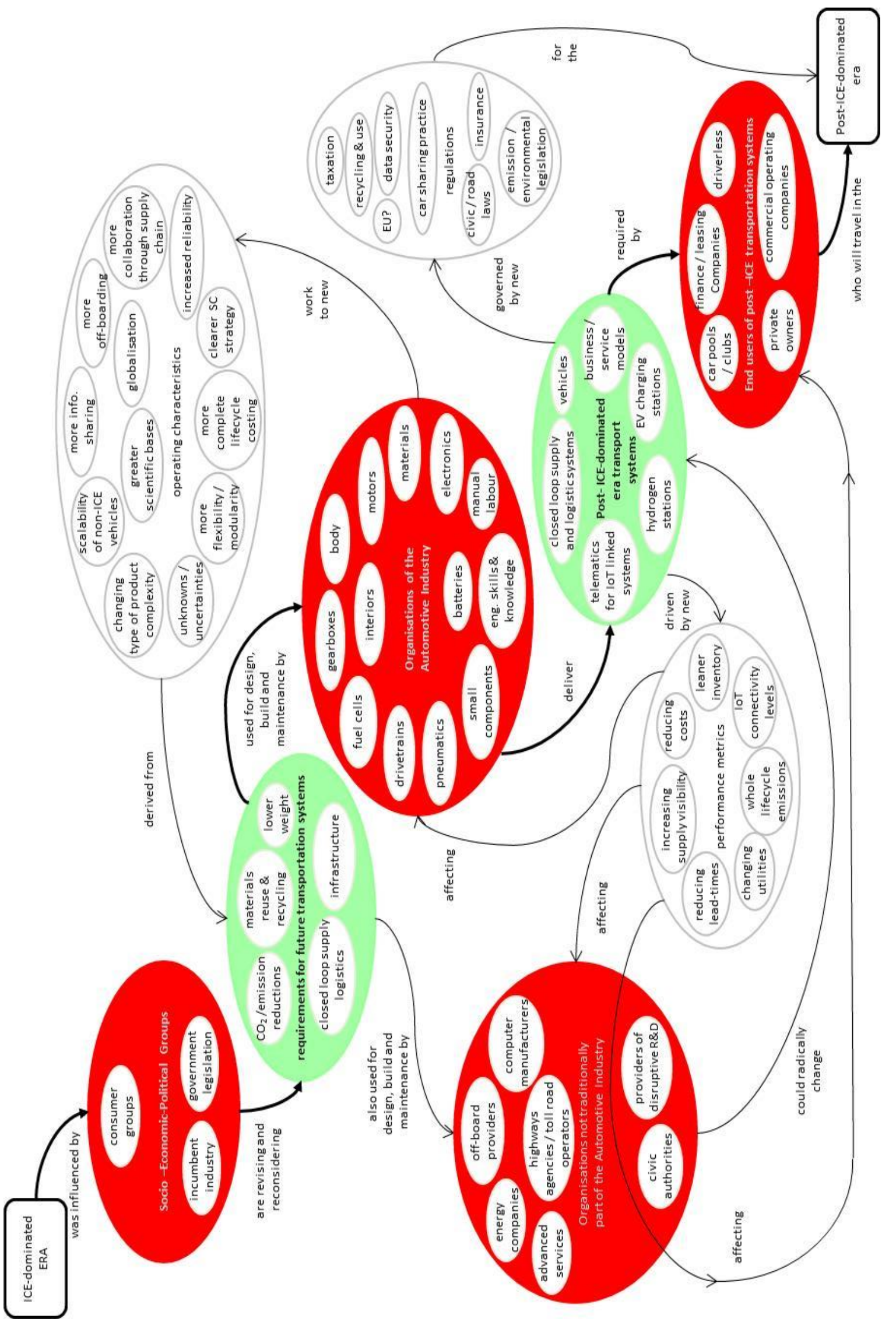


Figure 3: A summative conceptual framework for managing dependencies (as defined by RDT) in the EV Sector

Resource Dependence Level

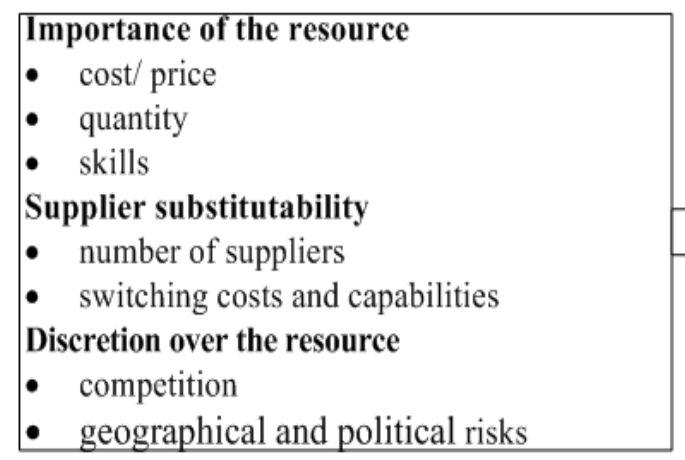

Strategies to manage Dependence Levels

Buffering strategies

- supply chain reconfiguration (inventories, new facilities)

- product/process reconfiguration (change of production process, integration of information technology)

\section{Bridging strategies}

- strategic partnership or collaboration

- co-operation 